\title{
The Effect of Nanoboron Nitride on Some Properties of Biopolymer Nanocomposites with Cellulose Nanofibrils and Nanoclays
}

\section{Učinak nanočestica boron-nitrida na neka svojstva biopolimernih nanokompozita s celuloznim nanovlaknima i nanočesticama gline}

Original scientific paper • Izvorni znanstveni rad

Received-prispjelo: 9. 6. 2017.

Accepted-prihvaćeno: 21. 2. 2018.

UDK: $630 * 863.31$

doi:10.5552/drind.2018.1737

\begin{abstract}
The aim of this study was to investigate the effect of nanoboron nitride (BN) as nano-fire retardant on some properties of polylactic acid (PLA) and polyhydroxybutyrate (PHB) biopolymer nanocomposites reinforced with cellulose nanofibrils (CNFs) and nanoclays (NC). BN particles, as nano-fire retardant, were added to enhance the thermal stability of the obtained biopolymer nanocomposites. PLA and PHB nanocomposites were prepared with a twin screw extruder and characterized with mechanical tests, TGA, and DSC. Densities of the PLA and PHB nanocomposites were found to decrease with the addition of NBN loading. The mechanical properties of biopolymer nanocomposites decreased, except for tensile modulus. According to TGA results, NBN loadings generally improved the thermal stability of the PLA and PHB nanocomposites. The degradation temperature for weight loss at $10 \%, 50 \%$ and $85 \%\left(T_{10 \%}, T_{50 \%}\right.$ and $\left.T_{85 \%}\right)$ increased with NBN loadings; the value of DTGmax was determined to improve with the loading of BN. DSC results showed that melt temperature $\left(T_{m}\right)$ and crystallization temperature $(T)$ generally increased with BN loadings, whereas crystallinity $(X c)$ decreased with BN loadings in PLA nanocomposites.
\end{abstract}

Keywords: nanoboron nitride, polymer nanocomposites, cellulose nanofibrils, nanoclays, biopolymers

SAŽETAK • Cilj ove studije bio je ispitati učinak nanočestica boron-nitrida (BN) kao usporivača gorenja na neka svojstva biopolimernih nanokompozita proizvedenih od polilaktične kiseline (PLA) i polihidroksibutirata (PHB) ojačanih celuloznim nanovlaknima (CNFs) i nanočesticama gline (NC). Nanočestice boron-nitrida (NBN), koji je usporivač gorenja, dodane su kako bi se povećala toplinska stabilnost proizvedenih biopolimernih nanokompozi-

\footnotetext{
${ }^{1}$ Authors are associated professors at Bartin University, Faculty of Forestry, Department of Forest Industrial Engineering, 74100, Bartin, Turkey. ${ }^{2}$ Author is professor at Istanbul University, Faculty of Forestry, Department of Forest Industrial Engineering, 34100, Istanbul, Turkey. Autori su izvanredni profesori Sveučilišta u Bartinu, Šumarski fakultet, Odjel za industrije na bazi šuma, Bartin, Turska. ${ }^{2}$ Autor je profesor Sveučilišta u Istanbulu, Šumarski fakultet, Odjel za industrije na bazi šuma, Istanbul, Turska.
} 
ta. Nanokompoziti PLA i PHB pripremljeni su uz pomoć dvostrukoga vijčanog ekstrudera i ispitani mehaničkim testovima te TGA i DSC analizom. Utvrđeno je da se gustoća PLA i PHB nanokompozita smanjuje dodatkom NBN čestica. Dodavanjem NBN čestica sva su se mehanička svojstva biopolimernih nanokompozita, osim modula vlačne čvrstoće, smanjila. Prema rezultatima TGA analize, dodane NBN čestice općenito poboljšavaju toplinsku stabilnost PLA i PHB nanokompozita. Dodavanjem NBN čestica povećana je temperatura degradacije za gubitak mase od 10, 50 i $85 \%\left(T_{10 \%}, T_{50 \%}\right.$ i $\left.T_{85 \%}\right)$, a poboljšala se i vrijednost DTG $G_{\max }$. Rezultati DSC analize pokazali su da se temperatura taljenja $\left(T_{m}\right)$ i temperatura kristalizacije $(T)$ povećavaju s povećanjem udjela NBN čestica, dok se kristaliničnost $(X)$ smanjuje s povećanjem količine NBN čestica u PLA nanokompozitu.

Ključne riječi: nanočestice boron-nitrida, polimerni nanokompoziti, celulozna nanovlakna, nanočestice gline, biopolimeri

\section{INTRODUCTION}

\section{UVOD}

Nanocomposite is a two-phase material, where one of the phases has at least one dimension in nanometer range (1-100 $\mathrm{nm})$ and generally nanoscale materials result in composites with superior thermal, barrier and mechanical properties (Oksman et al., 2006; Yao et al., 2002; Zanetti et al., 2001). Due to growing environmental awareness, new standards try to develop environmental friendly and biodegradable systems (Gorrasi et al., 2003; Lee et al., 2002; Oksman et al., 2006; Pluta et al., 2002; Ray et al., 2003). Polylactic acid (PLA) is one of the renewable biopolymer produced from lactic acid derived from sugar cane, potato and corn fermentation process (Aldana et al., 2014; Vink et al., 2003). PLA has high mechanical properties, low hydrophobicity, low cost and good process ability compared to other alternatives. For all this properties, PLA is the biopolymer with the greatest potential for plastic industries (Aldana et al., 2014; Molinaro et al., 2013; Svagan et al., 2012).

Polyhydroxybutyrate (PHB) is another biopolymer produced by fermentation of renewable resources (Steinbuchel, 2003; El-Hadi, 2014). PHB is a thermoplastic, biodegradable, renewable and environmentally friendly polymer. PHB also has a high crystallinity and low glass transition temperature $\left(T_{\mathrm{g}}\right)$ (El-Hadi, 2013; Fernandes et al., 2004). Initial bio-sourced polymers were used in short term applications but today environmental concerns and oil shortage issues expand their areas of usage. They are used for construction, transportation and electronics, where fire risk requires the use of fire retardant materials (Bocchini et al., 2012; Bourbigot, 2010; Wei et al., 2013). Some studies have been conducted with various fire retardants, which are an effective and convenient way to increase thermal properties of polymers (Lee et al., 2006; Yu et al., 2002; Zhang et al., 2011). However, the studies about the effect of boron nitride on thermal behavior of biopolymers are not enough. There are a few studies on biopolymer/BN composites. In a previous study, Pradhan et al. (2014) studied the effects of boron nitride on the thermal properties and tensile strength of starch biocomposites. The obtained results showed that thermal stability of the starch was increased with rising concentrations of boron nitride due to the addition of rigid nano $\mathrm{BN}$ with starch matrix, and the tensile strength of starch/BN bionanocomposites was found to increase with BN loading. In another study, Dash and Swain (2013) studied nanoboron nitride-soy protein composites. According to the obtained results, the degradation temperature of pure soy protein is lower than that of corresponding soy/BN nanocomposites. Hence, the thermal stability of soy/BN nanocomposite was found to be higher than that of virgin matrix due to the addition of thermally stable nanoboron nitride. Öner et al. (2016) used nano boron nitride to improve the thermal properties of polyhydroxybutyrate biocomposites. The barrier properties of the composites decreased with $\mathrm{BN}$ addition and it was found that the thermal stability of the composites with $\mathrm{BN}$ was higher than that of neat biopolymers. The differential scanning calorimetry results indicated that the addition of $\mathrm{BN}$ nanoparticles to the composites increased their crystallinity.

In this study, BN was used to improve the thermal properties of polylactic acid (PLA) and polyhydroxybutyrate (PHB) biopolymer nanocomposites prepared with twin screw extruder. The mechanical and morphological properties of biopolymer composites were also investigated.

\section{MATERIALS AND METHODS}

\section{MATERIJALI I METODE}

\subsection{Materials}

2.1. Materijali

Polyhydroxybutyrate (PHB) and polylactic acid (PLA) were supplied by Good Fellow, England. Density of PHB and PLA was $1.25 \mathrm{~g} / \mathrm{cm}^{3}$ and $1.24 \mathrm{~g} / \mathrm{cm}^{3}$, respectively. Cellulose nanofibrils $(\mathrm{CNF})$ and Nanoclays (NC), used as a reinforcing filler, were obtained from J. Rettenmaier \& Sohne (JRS) (Germany) and Nanocor (Canada). Hexagonal nano boron nitride (BN), used as fire retardant, was supplied by Boron Product Tech. San. Tic. A.Ş (BORTEK) (Eskisehir, Turkey). All reinforcing fillers and fire-retardant were dried for 24 hours at $80{ }^{\circ} \mathrm{C}$, and all materials were stored in sealed containers.

\subsection{Preparation of Biopolymer Nanocomposites (BNCs)}

2.2. Izrada biopolimernih nanokompozita (BNCs)

Polymers and fillers were mixed with speed mixer and then composites were compounded using a twin screw extruder (Aysa Instruments, Turkey). Rotor speed was $5 \mathrm{rpm}$ and process temperature was set at $160{ }^{\circ} \mathrm{C}-180{ }^{\circ} \mathrm{C}$. The extruded strand passed across a water bath so that this was pelletized.

The extruded nanocomposites were grounded with a lab-grinder and then the pellets dried for 3-4 
........ Al, Aydemir, Ayrilmis, Kaygin, Gunduz: The Effect of Nanoboron Nitride on Some...

Table 1 Formulations and codes for nanocomposites

Tablica 1. Sastav i oznake nanokompozita

\begin{tabular}{|c|c|c|c|}
\hline $\begin{array}{l}\text { Formulations } \\
\text { Sastav }\end{array}$ & $\begin{array}{l}\text { Codes } \\
\text { Oznaka }\end{array}$ & $\begin{array}{c}\text { Formulations (weight \%) } \\
\text { Sastav }\end{array}$ & $\begin{array}{l}\text { Codes } \\
\text { Oznaka }\end{array}$ \\
\hline PLA $+4 \%$ CNFs & LF & $\mathrm{PHB}+4 \% \mathrm{CNFs}$ & $\mathrm{HF}$ \\
\hline $\mathrm{PLA}+4 \% \mathrm{CNFs}+1 \% \mathrm{BN}$ & LF1 & $\mathrm{PHB}+4 \% \mathrm{CNFs}+1 \% \mathrm{BN}$ & HF1 \\
\hline $\mathrm{PLA}+4 \% \mathrm{CNFs}+5 \% \mathrm{BN}$ & LF5 & $\mathrm{PHB}+4 \% \mathrm{CNFs}+5 \% \mathrm{BN}$ & HF5 \\
\hline PLA $+4 \% C N F s+10 \%$ BN & LF10 & $\mathrm{PHB}+4 \% \mathrm{CNFs}+10 \% \mathrm{BN}$ & HF10 \\
\hline $\mathrm{PLA}+4 \% \mathrm{NCs}$ & $\mathrm{LC}$ & $\mathrm{PHB}+4 \% \mathrm{NCs}$ & $\mathrm{HC}$ \\
\hline $\mathrm{PLA}+4 \% \mathrm{NCs}+1 \% \mathrm{BN}$ & LC1 & $\mathrm{PHB}+4 \% \mathrm{NCs}+1 \% \mathrm{BN}$ & $\mathrm{HC} 1$ \\
\hline $\mathrm{PLA}+4 \% \mathrm{NCs}+5 \% \mathrm{BN}$ & LC5 & $\mathrm{PHB}+4 \% \mathrm{NCs}+5 \% \mathrm{BN}$ & HC5 \\
\hline $\mathrm{PLA}+4 \% \mathrm{NCs}+10 \% \mathrm{BN}$ & LC10 & $\mathrm{PHB}+4 \% \mathrm{NCs}+10 \% \mathrm{BN}$ & $\mathrm{HC} 10$ \\
\hline
\end{tabular}

hours before compression molding. The compression molding temperature was $175^{\circ} \mathrm{C}$, barrel temperature $170{ }^{\circ} \mathrm{C}$ and compression pressure 25 bar. The formulations of the composites are shown in Tab.1.

\subsection{Methods}

\subsection{Metode}

The properties of the PLA and PHB nanocomposites were analyzed with the standard tests such as density, flexure strength (FMOR) and modulus $(F M O E)$, tensile strength (TMOR) and tensile modulus (TMOE), Izod impact strength (Izod-IS), thermal properties (TG-DTA, DSC), and morphological characterization (SEM). The tension tests were conducted according to the American Society of Testing and Materials (ASTM) standard D 638-03 Type I. All tension tests were conducted at a rate of $0.2 \mathrm{in} . / \mathrm{min}$. The flexure tests were conducted according to ASTM D 790-03, Test Method 1, Procedure A, i.e. three-point loading system. The support span was $50.8 \mathrm{~mm}$, resulting in a span-to-depth ratio of $16( \pm 1)$. The tests were run at a test speed of $1.27 \mathrm{~mm} / \mathrm{min}$. The impact tests were conducted according to ASTM D 256-06. The notches were added using a NotchVIS machine manufactured by Ceast. The specimens were tested on a Resil $50 \mathrm{~B}$ impact test machine, manufactured by Ceast. At least eight specimens for all tests were tested for each composition, and the results are presented as an average for tested samples.

TG-DTA was tested using Hitachi STA 7300 analyzer with a heating rate of $10{ }^{\circ} \mathrm{C} / \mathrm{min}$ from $25{ }^{\circ} \mathrm{C}$ to $600{ }^{\circ} \mathrm{C}$, under nitrogen with a flow rate of $20 \mathrm{ml} / \mathrm{min}$ to avoid sample oxidation. DTA peaks, such as melting point $\left(T_{\mathrm{m}}\right)$ and decomposition point $\left(T_{\mathrm{d}}\right)$, were also measured during the thermogravimetric analysis; DSC analysis of the samples was performed using a Perkin Elmer analyzer on samples of about $5 \mathrm{mg}$. For all specimens, testing was performed by heat/cool methods. All samples were heated to $25^{\circ} \mathrm{C}$ to $300{ }^{\circ} \mathrm{C}$ at a ramp rate of $10{ }^{\circ} \mathrm{C} / \mathrm{min}$ and cooled at the same ramp rate. Melting temperature $\left(T_{\mathrm{m}}\right)$, crystallization temperature $\left(T_{\mathrm{c}}\right)$, melting enthalpy $\left(\Delta H_{\mathrm{m}}\right)$, crystallization enthalpy $\left(\Delta H_{\mathrm{c}}\right)$, crystallinity $\left(X_{\mathrm{c}}\right)$ of materials was determined from thermograms. The value of theoretical melting enthalpies of $100 \%$ crystalline PLA and PHB was 93.1 $\mathrm{J} / \mathrm{g}$ and $146 \mathrm{~J} / \mathrm{g}$, respectively. The samples were observed with an environmental scanning electron micro- scope (ESEM), the Tescan MAIA3 XMU-SEM at an acceleration voltage of $5 \mathrm{kV}$. The surface of all samples was sputter-coated with gold using a Denton sputter coater for enhanced conductivity.

\section{RESULTS AND DISCUSSION 3. REZULTATI I RASPRAVA}

The effects of BN on some properties of biopolymer nanocomposites (BNCs) were investigated in this study. Tab. 2 shows the density and mechanical properties of BNCs.

As seen in Tab. 2, the density for all BNCs generally decreased with BN loading. The decrease in the density was found to be higher as the loading of $\mathrm{BN}$ increased. The effects of boron nitride on the mechanical properties were generally found to be negative. It was determined that the effects of $\mathrm{BN}$ on the mechanical properties of PHB nanocomposites were higher than on PLA nanocomposites. For all that, in a study on $\mathrm{BN}$, the densities of PP composites were generally found to increase with BN loadings (Ayrilmis et al., 2013). It was determined that the decrease in the density of biopolymers was caused by gaps and porous structure generated by interactions between biopolymer and BN, as shown in Fig. 1. The morphological properties of the BNCs obtained with the help of SEM are presented in Fig. 1.

According to Fig. 1, the BN particles dispersed inside the matrix, and generally showed uniform dispersion in the matrixes. However, some BN aggregates were found in Fig. 1. SEM pictures show that the loading of BN caused the gaps of different diameters, and the porous structure was determined in both matrixes after BN loading. It can be said that this porous structure has a negative effect on the mechanical properties according to Tab.1. TGA analysis of biopolymer nanocomposites is given in Tab.3.

The thermal stability of all nanocomposites was affected by $\mathrm{BN}$ loading. The thermal stability at $T_{10 \%}$ improved with the addition of BN except for the PLA biopolymer nanocomposites (LF) with 1, 5, and $10 \%$ $\mathrm{BN}$. This showed that the $\mathrm{BN}$ loading increased the thermal stability of BNCs at initial response $\left(T_{10 \%}\right)$. The thermal stability at $T_{10 \%}$ was found to be better for HF and $\mathrm{HC}$ biopolymer nanocomposites with BN compared to PLA biopolymer nanocomposites with BN. As 
Al, Aydemir, Ayrilmis, Kaygin, Gunduz: The Effect of Nanoboron Nitride on Some... .......

Table 2 Mechanical properties of polymer nanocomposites with nanoboron nitride

Tablica 2. Mehanička svojstva polimernih nanokompozita s nanočesticama boron-nitrida

\begin{tabular}{|l|c|c|c|c|c|c|}
\hline $\begin{array}{l}\text { Composite } \\
\text { formulations (BNCs) } \\
\text { Sastav kompozita }\end{array}$ & $\begin{array}{c}\text { Density } \\
\text { Gustoća } \\
\mathbf{g} / \mathbf{c m}^{3}\end{array}$ & $\begin{array}{c}\text { TMOR } \\
\mathbf{M P a}\end{array}$ & $\begin{array}{c}\text { TMOE } \\
\mathbf{M P a}\end{array}$ & $\begin{array}{c}\text { FMOR } \\
\mathbf{M P a}\end{array}$ & $\begin{array}{c}\text { FMOE } \\
\mathbf{M P a}\end{array}$ & $\begin{array}{c}\text { Izod IS } \\
\mathbf{k J} / \mathbf{m}^{2}\end{array}$ \\
\hline LF & 1.18 & 50 & 2983.7 & 90.9 & 2983.7 & 4.8 \\
\hline LF1 & 1.14 & 48.2 & 4699.1 & 31.27 & 1547.1 & 2.3 \\
\hline LF5 & 1.08 & 37.5 & 4122.5 & 21.7 & 1069.1 & 2.7 \\
\hline LF10 & 1.07 & 32.1 & 3980.1 & 25.4 & 1174.2 & 2.4 \\
\hline LC & 1.18 & 55 & 3324.5 & 100.5 & 3324.5 & 3.9 \\
\hline LC1 & 1.17 & 20 & 2562.3 & 20.2 & 998.4 & 2.2 \\
\hline LC5 & 1.09 & 31.4 & 3858.3 & 30.1 & 1075.7 & 2.1 \\
\hline LC10 & 1.12 & 40.2 & 4682.4 & 31.5 & 1249.5 & 2.5 \\
\hline HF & 1.15 & 16 & 1436.7 & 27.4 & 1711.8 & 2.1 \\
\hline HF1 & 1.16 & 10.1 & 1418 & 7.9 & 515.3 & 1.9 \\
\hline HF5 & 1.11 & 9.1 & 1321 & 7.3 & 462.4 & 1.3 \\
\hline HF10 & 1.09 & 6.2 & 925 & 7.1 & 400.9 & 1.1 \\
\hline HC & 1.19 & 12.2 & 1233.5 & 21.9 & 2136.5 & 1.9 \\
\hline HC1 & 1.07 & 2.7 & 296 & 9.8 & 1009.2 & 1.6 \\
\hline HC5 & 1.18 & 2.1 & 325 & 9.4 & 885.4 & 1.4 \\
\hline HC10 & 1.16 & 5.1 & 755.8 & 8.7 & 739.2 & 1.7 \\
\hline
\end{tabular}

TMOR - tensile strength / vlačna čvrstoća; TMOE - tensile modulus / vlačni modul elastičnosti; FMOR - flexure strength / čvrstoća pri savijanju; FMOE - flexure modulus of elasticity / modul elastičnosti pri savijanju; Izod-IS - Izod impact strength / Izod udarna čvrstoća. See Table 1 for composite formulations. / Za sastav kompozita vidjeti tablicu 1.

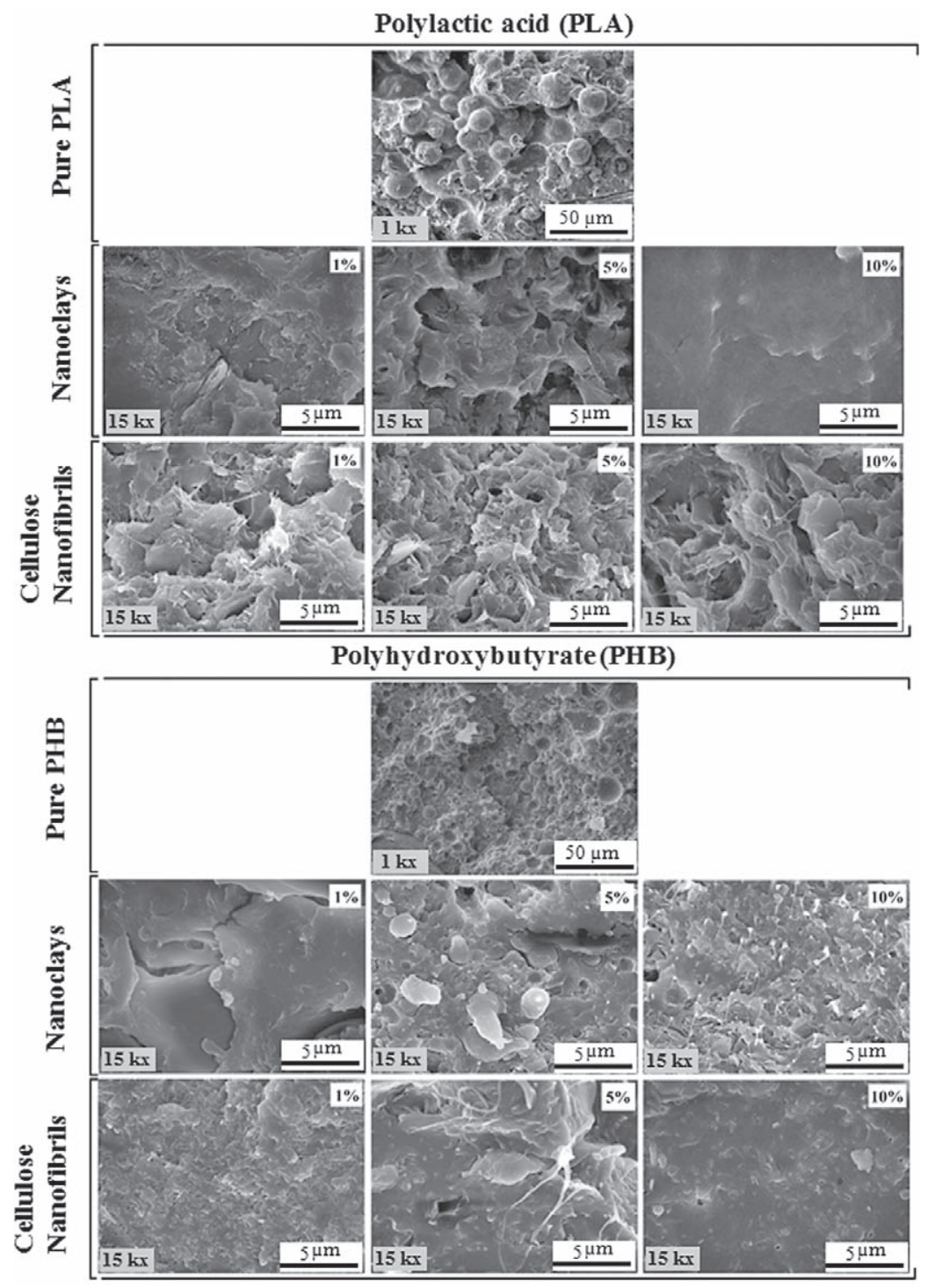

Figure 1 Biopolymer nanocomposites with BN

Slika 1. Biopolimerni nanokompoziti s nanočesticama boron-nitrida 
Table 3 Review of thermal properties of polymer nanocomposites

Tablica 3. Sažeti prikaz toplinskih svojstava polimernih nanokompozita

\begin{tabular}{|c|c|c|c|c|c|c|}
\hline \multirow[b]{2}{*}{$\begin{array}{c}\text { Formu- } \\
\text { lations }\end{array}$} & \multicolumn{3}{|c|}{ TGA, ${ }^{\circ} \mathrm{C}$} & \multirow{2}{*}{\begin{tabular}{|c|} 
DTG, ${ }^{\circ} \mathrm{C}$ \\
DTG $_{\text {max }}$ \\
${ }^{\circ} \mathrm{C}$
\end{tabular}} & \multicolumn{2}{|c|}{ DTA, ${ }^{\circ} \mathrm{C}$} \\
\hline & $\boldsymbol{T}_{10 \%}$ & $\begin{array}{c}T_{50 \%} \\
{ }^{\circ} \mathrm{C}\end{array}$ & $T_{85 \%}$ & & $\begin{array}{l}\mathrm{Tm} \\
{ }^{\circ} \mathrm{C}\end{array}$ & $\begin{array}{l}\mathrm{Td} \\
{ }^{\circ} \mathrm{C}\end{array}$ \\
\hline $\mathrm{HF}$ & 267.2 & 284.8 & 300.5 & 288.2 & 156.7 & 286.2 \\
\hline HF1 & 277.6 & 287.1 & 377.5 & 87.3 & 175.7 & 288.0 \\
\hline HF5 & 267.5 & 282.0 & 352.5 & 286.0 & 173.7 & 284.5 \\
\hline HF10 & 248.8 & 263.2 & 314.2 & 266.0 & 168.0 & 264.1 \\
\hline $\mathrm{HC}$ & 275.3 & 289.4 & 310.9 & 293.3 & 159.1 & 290.5 \\
\hline $\mathrm{HC} 1$ & 285.1 & 296.2 & 353.5 & 4.4 & 161.8 & 305.1 \\
\hline $\mathrm{HC} 5$ & 274.7 & 295.1 & 357.0 & 285.9 & 173.8 & 281.0 \\
\hline $\mathrm{HC} 10$ & 276.3 & 286.2 & 354.8 & 287.9 & 173.7 & 287.5 \\
\hline LF & 340.9 & 356.9 & 444.1 & 361.6 & 152.2 & 360.1 \\
\hline LF1 & 337.2 & 352.4 & 363.5 & 354.6 & 154.5 & 352.9 \\
\hline LF5 & 334.6 & 345.1 & 356.5 & 347.6 & 147.7 & 353.6 \\
\hline LF10 & 334.0 & 345.4 & 361.0 & 347.3 & 148.2 & 350.1 \\
\hline $\mathrm{LC}$ & 322.8 & 356.3 & 443.4 & 357.2 & 148.9 & 354.9 \\
\hline LC1 & 342.7 & 356.3 & 372.4 & 358.8 & 146.8 & 356.4 \\
\hline LC5 & 344.7 & 360.8 & 379.1 & 363.6 & 149.5 & 362.2 \\
\hline LC10 & 341.1 & 357.4 & 372.2 & 362.8 & 150.1 & 360.8 \\
\hline
\end{tabular}

the temperature was increased, the degradation temperature at $T_{50 \%}$ was found to be generally better for $\mathrm{HC}$ and LC biopolymer nanocomposites than for neat polymers. At $T_{85 \%}$, the thermal stability of $\mathrm{HF}$ and $\mathrm{HC}$ biopolymer nanocomposites increased as compared to neat biopolymer, whereas the thermal stability of LF an LC biopolymer nanocomposite was determined to decrease with the addition of BN. The best temperature in $D T G_{\max }$ was found to be $304.4{ }^{\circ} \mathrm{C}$ in $\mathrm{HC}$ with $1 \% \mathrm{BN}$, and $363.6^{\circ} \mathrm{C}$ in LC with $5 \% \mathrm{BN}$. The maximum $T_{\mathrm{m}}$ and $T_{\mathrm{d}}$ of BNCs were determined to be $175.7^{\circ} \mathrm{C}$ in $\mathrm{HF}$ with $1 \% \mathrm{BN}$, and $305.1{ }^{\circ} \mathrm{C}$ in $\mathrm{HC}$ with $1 \% \mathrm{BN}$, and $154.5^{\circ} \mathrm{C}$ in LF with $1 \% \mathrm{BN}$ and $362.2{ }^{\circ} \mathrm{C}$ in LC with $5 \% \mathrm{BN}$, respectively. The other thermal properties of biopolymer nanocomposites with $\mathrm{BN}$ were determined by differential scanning calorimetry. Tab. 4 shows the summary of DSC results of all biopolymer nanocomposites.

DSC analysis was conducted by cooling and heating of neat polymers and all biopolymer nanocomposites. The crystallization temperature $\left(T_{\mathrm{c}}\right)$ and melting temperature $\left(T_{\mathrm{m}}\right)$ changed with the loading of fillers. The highest value of Tc was found to be $109.5^{\circ} \mathrm{C}$ for $\mathrm{HC}$ without $\mathrm{BN}$ in $\mathrm{PHB}$ nanocomposites, and 116.6 ${ }^{\circ} \mathrm{C}$ for $\mathrm{LF}$ with $10 \% \mathrm{BN}$. The highest $\mathrm{Tm}$ was found to be $169.7^{\circ} \mathrm{C}$ for $\mathrm{HC}$ with $10 \% \mathrm{BN}$ for PHB nanocomposites, and $164.8^{\circ} \mathrm{C}$ for LF without BN for PLA nanocomposites. Seen as $X \mathrm{c}$ values, the crystallinity was found to decrease with the addition of BN except for $\mathrm{HC} 1$ and HC5.

\section{CONCLUSION}

\section{ZAKLJUČAK}

The addition of BN to biopolymer matrixes decreased the density of nanocomposites and mechanical properties except for TMOE of PLA nanocomposites.
Table 4 Review of DSC isotherms of nanocomposites Tablica 4. Sažeti prikaz DSC izotermi nanokompozita

\begin{tabular}{|c|c|c|c|c|c|}
\hline \multirow{2}{*}{$\begin{array}{c}\text { Formulations } \\
\text { Sastav } \\
\text { nanokompozita }\end{array}$} & \multicolumn{2}{|c|}{$\begin{array}{l}\text { Cooling } \\
\text { Hladenje }\end{array}$} & \multicolumn{2}{|c|}{$\begin{array}{c}\text { Heating } \\
\text { Zagrijavanje }\end{array}$} & \multirow[t]{2}{*}{$\begin{array}{c}X \mathbf{C} \\
\%\end{array}$} \\
\hline & $\begin{array}{l}T_{\mathrm{c}} \\
{ }^{\circ} \mathrm{C}\end{array}$ & $\underset{\mathrm{J} / \mathrm{g}}{\Delta \boldsymbol{H}_{\mathrm{c}}}$ & $\begin{array}{l}\boldsymbol{T}_{\mathrm{m}} \\
{ }^{\circ} \mathrm{C}\end{array}$ & $\underset{\mathrm{J} / \mathrm{g}}{\Delta \boldsymbol{H}_{\mathrm{m}}}$ & \\
\hline $\mathrm{HF}$ & 107.7 & 48.6 & 166.5 & 55.1 & 37.7 \\
\hline HF1 & 109.3 & 52.9 & 168.6 & 63.6 & 43.6 \\
\hline HF5 & 109.0 & 50.8 & 166.4 & 60 & 41.1 \\
\hline HF10 & 109.2 & 48.9 & 168.5 & 54.5 & 37.3 \\
\hline $\mathrm{HC}$ & 109.8 & 45.8 & 165.7 & 63.1 & 42.2 \\
\hline $\mathrm{HC} 1$ & 109.5 & 41.8 & 153.4 & 42.8 & 29.3 \\
\hline HC5 & 108.2 & 40.4 & 169.6 & 49.7 & 34 \\
\hline HC10 & 108.2 & 54.8 & 169.7 & 58.9 & 40.3 \\
\hline LF & 110.0 & 12.8 & 164.8 & 48.4 & 52.0 \\
\hline LF1 & 115.6 & 27.1 & 152.2 & 21.2 & 14.5 \\
\hline LF5 & 115.1 & 20.3 & 151.8 & 22.2 & 15.2 \\
\hline LF10 & 116.6 & 21.3 & 153.4 & 24.5 & 16.8 \\
\hline LC & 108.8 & 20.8 & 155.5 & 38.3 & 41.1 \\
\hline LC1 & 115.3 & 18.7 & 154.6 & 19.9 & 13.6 \\
\hline LC5 & 115.2 & 22.1 & 153.6 & 21.4 & 14.6 \\
\hline LC10 & 113.7 & 22.4 & 153.3 & 22.8 & 15.6 \\
\hline
\end{tabular}

It was found that the effects of $\mathrm{BN}$ were higher on the mechanical properties of PHB nanocomposites than on PLA nanocomposites. The SEM result showed that BN particles dispersed inside the matrix, and generally showed uniform dispersion in the matrixes. However, some BN aggregates were found in the SEM images. Thermal stability of biopolymer nanocomposites was found to improve with the addition of BN. The addition of BN showed improvement of $T_{10 \%}, T_{50 \%}$, and $T_{85 \%}$. In DSC analysis, $T_{\mathrm{m}}$ and $T_{\mathrm{c}}$ generally increased with the addition of fillers, and $X_{\mathrm{c}}$ was also raised with the increase of $\Delta H_{\mathrm{c}}$ and $\Delta H_{\mathrm{m}}$.

\section{Acknowledgement - Zahvala}

The authors would like to thank Bartin University for providing support for the project 2014-FENA-008.

\section{REFERENCES}

\section{LITERATURA}

1. Aldana, D. S.; Villa, E. D.; Hernández, M.; Dios, D.; Sanchez, G. G.; Cruz, Q. R.; Gallardo, S. F.; Castillo, H. P.; Casarrubias, L. B., 2014: Barrier Properties of Polylactic Acid in Cellulose Based Packages Using Montmorillonite as Filler. Polymers, 6: 2386-2403. https://doi.org/10.3390/polym6092386.

2. ASTM D 638-03, 2003. Standard Test Method for Tensile Properties of Plastics, ASTM International, West Conshohocken, PA.

3. ASTM D 790-03, 2003. Standard Test Methods for Flexural Properties of Unreinforced and Reinforced Plastics and Electrical Insulating Materials, ASTM International, West Conshohocken, PA.

4. Ayrilmis, N.; Kaymakcı, A.; Dundar, T.; Ozdemir, F.; Kwon, J. H., 2013: Mechanical and Thermal Properties of Wood Plastic Composites Reinforced With Hexagonal Boron Nitride. Polymer Composites, 35: 194-200. https://doi.org/10.1002/pc.22650. 
5. Bocchini, S.; Camino, G., 2012: Flammability and Thermal Stability in Clay/Polyesters Nano-Biocomposites. In: Environmental Silicate Nano-Biocomposites" (eds. Avérous L., Pollet E.). London: Springer London, 2012, pp. 265-285.

6. Bourbigot, S.; Fontaine, G., 2010: Flame retardancy of polylactide: an overview. Polym. Chem., 1: 1413. https://doi.org/10.1039/C0PY00106F.

7. Dash, S.; Swain, S. K., 2013: Synthesis of thermal and chemical resistant oxygen barrier starch with reinforcement of nano silicon carbide. Carbo. Polym., 97(2): 758763. https://doi.org/10.1016/j.carbpol.2013.05.061.

8. El-Hadi, A. M., 2013: Influence of microcrystalline cellulose fiber (MCCF) on the morphology of poly(3-hydroxybutyrate) (PHB). Colloid Poly. Sci., 291: 743-756. https://doi.org/10.1007/s00396-012-2784-x.

9. El-Hadi, A. M., 2014: Investigation of the effect of nanoclay type on the non-isothermal crystallization kinetics and morphology of poly(3(R)-hydroxybutyrate) PHB/ clay nanocomposites. Polym. Bull., 71: 1449-1470. https://doi.org/10.1007/s00289-014-1135-0.

10. Fernandes, E. G.; Pietrini, M.; Chiellini, E., 2004: Biobased polymeric composites comprising wood flour as filler. Biomacromolecules, 5: 1200-1205. https://doi.org/10.1021/bm034507o.

11. Gorrasi, G.; Tortora, M.; Vittoria, V.; Pollet, E.; Lepoittevin, B.; Alexandre M.; Dubois, P., 2003: Vapor barrier properties of polycaprolactone montmorillonite nanocomposites: effect of clay dispersion. Polymer, 44 (8): 2271-2279. https://doi.org/10.1016/S0032-3861(03)00108-3.

12. Lee, G. W.; Park, M.; Kim, J.; Lee, J. I.; Yoon, H. G., 2006: Enhanced thermal conductivity of polymer composites filled with hybrid filler. Composites part A: Applied Science and Manufacturing, 37: 727-734. https://doi.org/10.1016/j.compositesa.2005.07.006.

13. Lee, S. R.; Park, H. M.; Lim, H.; Kang, T.; Li, X.; Cho, W. J.; Chang-sik, Ha., 2002: Microstructure, tensile properties, and biodegradability of aliphatic polyester/ clay nanocomposites. Polymer; 43 (8): 2495-2500. https://doi.org/10.1016/S0032-3861(02)00012-5.

14. Molinaro, S.; Cruz Romero, M.; Boaro, M.; Sensidoni, A.; Lagazio, C.; Morris, M.; Kerry, J., 2013: Effect of nanoclay-type and PLA optical purity on the characteristics of PLA-based nanocomposite films. J. Food Eng., 117: 113-123.

https://doi.org/10.1016/j.jfoodeng. 2013.01.021.

15. Oksman, K.; Mathew, A. P.; Bondeson, D.; Kvien, I., 2006: Manufacturing process of cellulose whiskers/polylactic acid nanocomposites. Composites Science and Technology, 66: 2776-2784. https://doi.org/10.1016/j.compscitech.2006.03.002.

16. Öner, M. A.; Çöl, A., Pochat-Bohatier, C.; Bechelany, M., 2016: Effect of incorporation of boron nitride nanoparticles on the oxygen barrier and thermal properties of poly (3-hydroxybutyrate-co-hydroxyvalerate). RSC Adv., 6: 90973-90981.

https://doi.org/10.1039/C6RA19198C.

17. Pluta, M.; Galeski, A.; Alexandre, M.; Paul, M. A.; Dubois, P., 2002: Polylactide/ montmorillonite nanocom- posites and microcomposites prepared by melt blending: structure and some physical properties. J. Appl. Polym. Sci., 86 (6): 1497-1506.

https://doi.org/0.1002/app.11309.

18. Pradhan, G. C.; Behera, L.; Swain, S. K., 2014: Effects of Boron Nitride Nano powder on Thermal, Chemical and Gas Barrier Properties of Starch. Chinese Journal of Polymer Science, 32 (10): 1311-1318. https://doi.org/10.1007/s10118-014-1511-0.

19. Ray, S. S.; Okamoto, K.; Okamoto, M., 2003: Structureproperty relationship in biodegradable poly(butylene succinate)/layered silicate nanocomposites. Macromolecules, 36 (7): 2355-2367. https://oi.org/10.1021/ma021728y.

20. Steinbuchel, A., 2003: Biopolymers: general aspects and special applications, vol 10. Wiley, Weinheim, pp 516530.

21. Svagan, A. J.; Åkesson, A.; Cárdenas, M.; Bulut, S.; Knudsen, J. C.; Risbo, J.; Plackett, D. 2012: Transparent films based on PLA and montmorillonite with tunable oxygen barrier properties. Biomacromolecules, 13: 397405. https://doi.org/10.1021/bm201438m.

22. Vink, E. T.; Rabago, K. R.; Glassner, D. A.; Gruber, P. R., 2003: Applications of life cycle assessment to NatureWorks $^{\mathrm{TM}}$ polylactide (PLA) production. Polym. Degrad. Stab., 80: 403-419.

https://doi.org/10.1016/S0141-3910(02)00372-5.

23. Wei, P.; Bocchini, S.; Camino, G., 2013: Flame retardant and thermal behavior of polylactide/expandable graphite composites. Polimery, 5: 361 .

24. Yao, K. J.; Song, M.; Hourston, D. J.; Luo, D. Z., 2002: Polymer/layered clay nanocomposites: 2 polyurethane nanocomposites. Polymer, 43 (3): 1017-1020. https://doi.org/10.1016/S0032-3861(01)00650-4.

25. Yu, S. Z.; Hing, P.; Hu, X., 2002: Thermal conductivity of polystyrene-aluminum nitride composite. Composites Part A: Applied Science and Manufacturing, 33: 289292. https://doi.org/10.1016/S1359-835X(01)00107-5.

26. Zanetti, M.; Gamino, G.; Thomann, R.; Mulhaupt, R., 2001: Synthesis and thermal behaviour of layered silicate-EVA nanocomposites. Polymer, 42 (10): 4501-4507. https://doi.org/10.1016/S0032-3861(00)00775-8.

27. Zhang, S.; Cao, X. Y.; Ma, Y. M.; Ke, Y. C.; Zhang, J. K.; Wang, F. S., 2011: The effects of particle size and content on the thermal conductivity and mechanical properties of $\mathrm{Al}_{2} \mathrm{O}_{3}$ /high density polyethylene (HDPE) composites. eXPRESS Polymer Letters, 5 (7): 581-590. https://doi.org/10.3144/expresspolymlett.2011.57.

\section{Corresponding address:}

Assoc. Prof. DENIZ AYDEMIR, Ph.D.

Bartin University, Faculty of Forestry

Department of Forest Industrial Engineering

74100, Bartin, TURKEY

E-mail: denizaydemir@bartin.edu.tr. 